\title{
IN SEARCH OF SOFT POWER Does Foreign Public Opinion Matter for US Foreign Policy?
}

\author{
By BENJAMIN E. GOLDSMITH and YUSAKU HORIUCHI*
}

$\mathrm{D}$

OES "soft power" matter in international relations? Specifically, when the United States seeks cooperation from countries around the world, do the views of their publics about US foreign policy affect the actual foreign policy behavior of those countries? We examine this question using multinational surveys covering fifty-eight countries, combined with information about their foreign policy decisions in 2003, a critical year for the US during the post-9/11 period.

We draw our basic conceptual framework from Joseph Nye, who coined the term "soft power." 1 According to Nye, soft power is "the ability to get what you want through attraction rather than coercion or payments." ${ }^{2}$ This is an especially appropriate framework for us because, as Nye puts it, "soft power is about mobilizing cooperation from others." 3 As we do in this article, he frequently uses public opinion surveys regarding attitudes in foreign countries toward the US and its policies. ${ }^{4}$ It is also appropriate because the effectiveness of soft power hinges on the targeted country's public attitudes (that is, favorability) toward the country wielding, or attempting to wield, international influence (in this study, the US).

*Earlier versions of this article were presented at the United States Study Centre (USSC), University of Sydney, on August 11, 2009; the Center on Public Diplomacy, University of Southern California, on January 29, 2010; and the School of International Relations and Pacific Studies, University of California, San Diego, on February 2, 2010. We thank Nick Cull, Ellis Krauss, Graeme Gill, Murray Goot, Simon Jackman, Brendon O'Connor, Shirley Scott, Fred Teiwes, other seminar participants, and the anonymous reviewers for useful comments. We are grateful to the Ussc for funding through the 2009 research grants program and to Takashi Inoguchi and Emma Thomas for providing parts of the data for analysis. For very capable research assistance, we thank Weilin Chiu, William Courcier, Robert Flawith, Keira Glasgow, and Jens Hansen-Ölmedal.

${ }^{1}$ Nye 1990; Nye 2004.

${ }^{2}$ Nye 2004, $x$.

${ }^{3}$ Nye 2004, 61.

${ }^{4}$ For example, in only the first two chapters of his 2004 book, Nye uses such international opinion data to illustrate US soft power on pages 12, 14, 18, 29-30, 36-37, 39, 42-43, and 69-72.

World Politics 64, no. 3 (July 2012), 555-85

Copyright (C) 2012 Trustees of Princeton University

doi: S0043887112000123 
In recent years, the concept has gained wide currency in academia, among pundits, and among some foreign policy makers. ${ }^{5}$ Although it may have intuitive or rhetorical appeal, little systematic evidence that soft power actually affects international relations has been produced. In a well-known recent study, Keohane and Katzenstein find no effect of anti-American views on a range of diplomatic issues pursued by the US, including some examined in this article. ${ }^{6}$ Few other studies address the question rigorously, and fewer still employ systematic analysis of large data sets. ${ }^{7}$ We contend that the role of public opinion as a meaningful factor in the dynamics of international relations deserves more general theoretical attention and empirical evaluation. ${ }^{8}$

In this article, we attempt to offer substantial new contributions, both to the refinement of the theory of soft power and to its systematic empirical examination. Our objective is to improve understanding of the conditions under which soft power might have "hard" political consequences: identifiable foreign policy choices that can be tied empirically to mass-level perceptions. We argue that Nye's theory is difficult, if not impossible, to test empirically, and so we propose a further specification. In Nye's original argument, the foreign public's affinity for (American) values, culture, institutions, and past policies of all sorts are "currencies" of soft power. ${ }^{9}$ By contrast, we focus on an underemphasized element of Nye's approach-foreign policy views of the public in the targeted countries - that we suggest is crucial for the country attempting to use soft power to favorably affect policy outcomes. As we discuss in the next section, we see Nye's currencies of soft power as structural or underlying factors, constituting a filter through which current foreign policies of a country are perceived, rather than factors directly affecting the decisions of foreign policy makers. We argue that in international relations soft power manifests itself in views held by country B's mass public about country A's foreign policy.

With this theoretical focus, we develop a set of testable expectations about whether foreign public opinion actually matters for international outcomes and, if it does, when it may be most or least effective. Empiri-

${ }^{5}$ For example, see Zubrow 2009.

${ }^{6}$ Keohane and Katzenstein 2007.

${ }^{7}$ Exceptions are Datta 2009; and Dragojlovic 2009.

${ }^{8}$ We acknowledge the contributions of earlier theorists, especially Putnam 1988; Risse-Kappen 1991; and Keohane and Nye 1977. Of these, Putnam's two-level games approach is the most focused on the type of short-term political outcomes that concern us here, rather than underlying institutional or structural effects. But its attention to dynamics of public opinion, or to other targeted persuasion and influence without threat or inducements, is minimal (e.g., p. 436).

${ }^{9}$ Nye 2004, 31. 
cally, we analyze three distinct outcome variables and show that foreign opinion has a significant and large effect on troop commitments to the war in Iraq, even after controlling for various hard power factors. It also has significant, albeit small, effects on policy toward the International Criminal Court and on voting decisions in the UN General Assembly. These results of regression analysis support our refined theoretical argument about soft power: public opinion about US foreign policy in foreign countries does affect their policies toward the U.S., but this effect is conditional on the salience of an issue for mass publics.

We emphasize that our contributions go beyond the literature on soft power. We acknowledge the rich literature on the influence of public opinion on public policy, but the existing studies focus almost exclusively on the relationship between opinion and policy within the US. ${ }^{10}$ However, we demonstrate the importance of public opinion (about the US) for policy outcomes outside of the US, a question that has rarely been studied. We also emphasize that our study is about the influence of public opinion on foreign policy; by contrast, most of the studies of which we are aware focus on the effects of opinion on domestic policy. ${ }^{11}$

In the remainder of the article, we first discuss our focus on foreign policy views as the pivotal factor in soft power dynamics, presenting two testable hypotheses. We then discuss our data and variables. After examining the results of our analysis, we conclude by discussing the implications for understanding international relations and avenues for future research.

\section{Theory And Hypotheses}

In this section, we first address Nye's focus on cultural aspects of soft power, attempting to clarify the connections to foreign policy and proposing a refined theory of the soft power process. We then derive two hypotheses about the effects of public opinion on foreign policy behavior and introduce the specific cases used in our analysis.

\section{A Refined Theory of Soft Power}

Nye draws on the ideas of Bachrach and Baratz to develop his soft power framework, focusing in particular on their "second face of power." 12 This refers to "the practice of limiting the scope of actual decisionmaking to 'safe' issues by manipulating the dominant community values,

${ }^{10}$ For example, Erikson, MacKuen, and Stimson 2002; Stimson 2004.

${ }^{11}$ Exceptions are Jacobs and Page 2005; and Sobel 2001.

${ }^{12}$ Nye 2004, 150n5. 
myths, and political institutions and procedures. To pass over this is to neglect one whole 'face' of power." ${ }^{13}$ This is fundamentally a description of agenda setting at the structural level of basic beliefs and institutions. With this foundation, it is perhaps clearer why Nye's framework for soft power emphasizes culture and longer-term latent effects. ${ }^{14}$

By stressing general factors that show limited variation over time, however, we feel that Nye fails to provide a theory for understanding when soft power affects international outcomes. Indeed, he writes, "[w] hether that attraction in turn produces desired policy outcomes has to be judged in particular cases." 15 But he does not specify how this is to be judged. This leaves the causal mechanisms of soft power, as well as their empirical implications, underspecified. Nor is there any indication of what the relative importance of each currency of soft power is for any given foreign policy outcome desired by the US. An example from Nye's own writing is indicative: while "American music and films are more popular in Britain, France, and Germany than they were 20 years ago," he finds that US policies received less support there than they did 20 years prior. ${ }^{16}$ Is this pattern consistent with the soft power thesis, or does it contradict it? In short, it is not readily apparent how the theory might be tested.

We argue that it is the public views about current foreign policyrather than underlying public affinity-that are directly relevant in shaping international outcomes. For the case of US soft power, foreign decision makers today care about their public's potential reactions to specific foreign policy choices, such as signing a treaty or going to war, rather than the popularity of Nike goods, admiration for the US Bill of Rights, or opinions about the Vietnam War. Culture, values, institutions, and (past) policies - the four currencies of soft power-are important latent or underlying factors, public perceptions of which play a role in how views about current foreign policy are formed, but on their own are relatively indeterminate, as Nye himself suggests. ${ }^{17}$

${ }^{13}$ Bachrach and Baratz 1963, 632.

${ }^{14}$ For example, see Nye 2004, 15. Entman's (2008) model of US "mediated public diplomacy" is similar to Nye's framework in its emphasis on relatively invariant factors. In Entman's case, these include the congruence of the target country's political culture with that of the US, regime type, and news media system.

${ }^{15}$ Nye 2004, 60.

${ }^{16}$ Nye 2004, 128.

${ }^{17}$ Nye 2004, 31. It is important to point out that there need not be homogenous or linear relationships between the latent soft power currencies and the manifest foreign policy views. For example, strong affinity for US values, such as respect for human rights, might actually reduce support for a US policy that is believed to be inconsistent with those values, such as the US "enemy combatant" detention system at Guantanamo Bay. While such issues deserve exploration, further investigation is beyond the scope of this article. 
Countries, perhaps especially major powers like the US, can have relatively enduring general images in the minds of people around the world. ${ }^{18}$ Each new issue on the global political agenda will almost certainly be interpreted in light of such preexisting views. We anticipate, however, considerable scope for time-specific and context-specific variation regarding the extent to which, and how, such general images shape views on each new issue. A case in point would be the varying difficulty the US had convincing its NATO allies and their publics to accept intermediate range nuclear missiles on their territory in the early 1980s and to remove them later on in that decade. ${ }^{19}$

Given our focus on public opinion about a country's foreign policy, we therefore refine and extend a theory of the soft power process. We focus on the specific process through which soft power has a policy consequence, dividing it into six stages. First, there must be an attempt to communicate a message from one state (country A) to an audience or audiences in another state (country B). Second, that message must be received by at least one relevant audience in the target state. ${ }^{20}$ Third, there is a process of assessing the meaning and implications of the message, as well as communication within the target state about it. ${ }^{21}$ Fourth, there either is or is not some politically relevant change in views or priorities in response to the message. We argue that general views about country A's foreign policy are likely to be relevant for specific issues in country B's relationship with country A. Fifth, if an issue is salient for the mass public (or another pivotal group), any shift in views or priorities may change the domestic political calculus on the issue, shifting the balance of costs and benefits for changing foreign policy behavior (discussed further below). Finally, if the decision makers perceive the costs to be sufficiently outweighed by the benefits, this will translate into a change in actual foreign policy behavior.

\section{Hypotheses about Soft Power Effects}

An important division in this process is that between country A's efforts to influence opinion in country B and the translation of opinion

${ }^{18}$ Isernia, Juhász, and Ratinger 2002.

${ }^{19}$ Eichenberg 1989; Eichenberg 1993.

${ }^{20}$ In this article, given the limited availability of cross-national data of elite opinion, we deal only with mass public opinion. It would be interesting to consider preferences of elite factions, as well as the interaction between mass and elite views, and we note the contributions of Gourevitch 1978 and Risse-Kappen 1991 as possible starting points for further work here.

${ }^{21}$ For example, political leaders might make statements in response to the foreign message, attempting to spin or frame the issue for the mass public. The political context of the target state is important here, including the role of the news media, as Entman 2008 points out regarding public diplomacy. 
in country B into its foreign policy outcomes. For the purposes of this article, we focus on the latter. ${ }^{22}$ This is an essential but underinvestigated aspect of transnational influence, a necessary condition of soft power. Without some effect on international outcomes, the term soft power would, of course, be a misnomer. While Nye's framework does not specify how generic attraction is translated into foreign policy influence ("power"), our approach proposes that this happens via foreign policy views among the mass public.

Specifically, we formulate two testable hypotheses regarding the effects of public opinion about the US on foreign policy behavior. First, we expect that public opinion about US foreign policy will have an effect on behavior of states toward the US. Fundamentally, we expect the effect of soft power to run through public opinion about US foreign policy, because leaders must be attentive to the balance of political costs and benefits before taking the foreign policy decisions US leaders prefer them to. ${ }^{23}$

Hypothesis 1. Public opinion about US foreign policy in other countries affects the foreign policies of those countries toward the US.

It is important to emphasize that we do not reduce foreign policy views to views on specific issues - this overly narrow operational definition would dilute our ability to test soft power effects. The soft power argument rests on the expectation that some general orientation in country B toward country A will affect a range of outcomes in country B's relations with country A. Therefore, we must measure some general positive or negative assessment of country A that can be expected to have direct relevance for foreign policy.

While general orientation toward country A's foreign policy is the relevant causal variable in our empirical analysis, we argue that the magnitude of its effect may be heterogeneous. Specifically, a more refined expectation emerging from our framework is that issues of greater salience or importance to key groups within a state-particularly the mass public-will be more susceptible to soft power effects.

Hypothesis 2. The effect of public opinion about US foreign policy in other countries on foreign policy decisions relevant for the US will be

\footnotetext{
${ }^{22}$ We developed testable hypotheses regarding the first stages of the soft power process, affecting opinion, elsewhere (Goldsmith and Horiuchi 2009).

${ }^{23}$ We do not necessarily assume that only in democratic political systems are decision makers concerned with support among the mass public. In our preliminary analysis, we attempted to estimate the effect of public opinion interacted with regime type (for example, democracy). Interestingly, we found no significant effect, although we are cautious about this result due to the relatively small number of observations.
} 
most evident when the issue at stake is salient for the mass publics in the those countries.

This is so because support for, or opposition to, a country's leadership, and thus the balance of political costs and benefits for the decision maker, will more likely be affected by issues of importance to the public. If an issue is of little salience to the mass public, then the foreign policy choice will not be likely to affect the public's overall evaluation of the decision maker. If an issue is of high salience, however, then a choice that goes against the preference of the public will shift the balance of political costs associated with a given foreign policy decision. Thus, in anticipation of political consequences, decision makers will take heed of opinion on salient issues but will be more likely to ignore opinion on nonsalient issues. As Lax and Philips write, "political actors will shift attention to [public] opinion when salience is high and away from it when low ... higher salience means greater responsiveness." ${ }^{24}$

Our framework has implications for the issues we examine. These are (1) the commitment of troops to the US-led war in Iraq, (2) compliance with US wishes regarding a waiver exempting its nationals from the jurisdiction of the International Criminal Court (ICC), and (3) annual voting patterns in the UN General Assembly (UNGA) on issues highlighted as important by the US in that year.

Our assumptions about the relative salience of these issues are, at this stage, necessarily generic for all countries. ${ }^{25}$ We expect that UNGA voting will be of low salience, since this is largely a symbolic act. The decision to grant so-called Article 98 immunity from the ICC to US nationals is perhaps a more substantive foreign policy choice but also highly specific and possibly obscure in the public mind. The choice of whether or not to commit troops to support the US in a widely unpopular military action is the most salient issue for mass publics and thus the one that will be most susceptible to the effects of public opinion.

How might we assess the level of salience of these three issues internationally? Media coverage should be an appropriate metric, as there is a wealth of evidence demonstrating that the frequency of news media coverage of an issue is closely associated with the importance or priority that the issue has for the public. ${ }^{26}$ Figure 1 presents monthly data on

\footnotetext{
${ }^{24}$ Lax and Philips 2009, 370.

${ }^{25}$ In future research, we might refine our assumptions about issue salience based on target-country regime type, region, or other country-specific factors (also see fn. 23).

${ }^{26}$ Whether this is due to the effects of media agenda setting (McCombs and Shaw 1972), to the media following public preferences (Tahk et al. 2009), or to exogenous factors is an important question, but one not relevant for our purposes of demonstrating relative issue salience.
} 


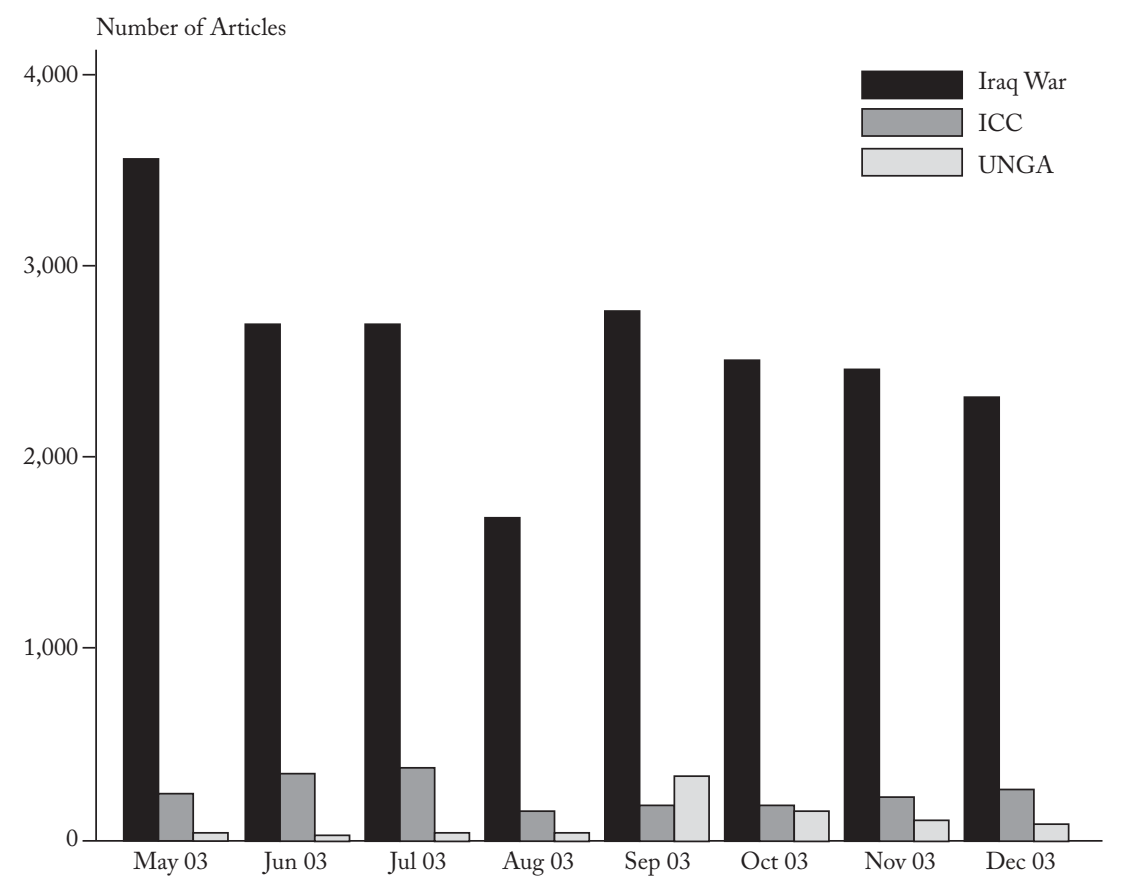

FiguRe 1

Issue Salience Measured by Number of Articless ${ }^{a}$

\begin{abstract}
${ }^{a}$ Data represent the total number of articles per month based on a search of the Factiva database (http://global.factiva.com) in the following sources: "Major News and Business Publications" for Africa, Asia Pacific, Australia / New Zealand, Canada, Europe, Latin America, Middle East, and UK. The search terms were: "Iraq SAME (United States OR U.S. OR Bush) $A N D$ war" or "International Criminal Court OR ICC" or "(United Nations General Assembly OR UN General Assembly OR UNGA) NOT Iraq." This search strategy requires that Iraq be mentioned in the same paragraph as the US and limits hits to instances in which the word "war" is used, thus setting restrictive requirements for our expected salient issue, while allowing any articles mentioning the ICC, and any non-Iraq-related articles mentioning the UNGA, thus setting liberal requirements for our expected nonsalient issues. The 58th UNGA was convened in September 2003, corresponding to the jump in media coverage.
\end{abstract}

international print media coverage (outside of the US) of these three issues, for the period May through December 2003. This strongly corresponds to our expectations about issue salience, with the Iraq war generating about ten times as many articles per month as the ICC and usually more than twenty times as many articles as the UNGA. We will discuss each of these issues more specifically in the next section. 


\section{DATA AND VARIABLES}

To test our hypotheses, we use multinational surveys covering fiftyeight non-US countries for our key independent variables and information about their foreign policy decisions during 2003 as dependent variables. Specifically, our independent variable (Opinion about US foreign policy) is the difference between the aggregated (in ratio) positive and negative response to the following survey item: ${ }^{27}$

- "Generally, do you think American foreign policy has a positive effect on <your country>, a negative effect or does American foreign policy have no effect on <your country>?"

The data are taken from surveys conducted by Gallup International from June 2002 to May 2003: Voice of the People September 2002, Gallup International Iraq Poll 2003, and Gallup International Post-War Iraq Poll 2003. ${ }^{28}$ For each country, we take the average of these surveys. ${ }^{29}$

We use the Gallup International surveys for two reasons. First, they are among the most comprehensive multinational surveys satisfying the "time-order" condition, given our theoretical expectation that opinion affects these outcomes; namely, they measure opinion prior to the foreign policy outcomes of interest. The selection of countries, while not random, includes over a quarter of all countries in the world, with a range of important political, economic, and historical relationships with the US. ${ }^{30}$

\footnotetext{
${ }^{27}$ We note that Nye $(2004,53)$ also discusses the "ratio of the positive to the negative dimensions" of views of the US.

${ }^{28}$ We obtained aggregated data for the Voice of the People survey from Professor Takashi Inoguchi, University of Niigata Prefecture (Japan). The aggregated data for the 2003 Iraq Poll and Post-War Iraq Poll are available from the Gallup International Web site, at http://www.gallup-international .com. Details regarding the methodology of each survey in each country, which we summarize below, are also available there. The Voice of the People September 2002 poll covers thirty-seven countries (including the US) with a combined non-US sample size of 27,218, with field dates from June 25 to September 1, 2002, varying by country. The Gallup International Iraq Poll 2003 covers forty countries (including the US) with a combined non-US sample size of 28,783, with field dates from January 9 to 29, 2003, varying by country. The Gallup International Post-War Iraq Poll 2003 covers forty-five countries (including the US) with a combined non-US sample size of 34,014, field dates from April 14 to May 8, 2003, varying by country. In most countries, samples are drawn nationally and questions are asked through face-to-face (mainly less developed countries) or telephone (mainly developed countries) interviews.

${ }^{29}$ As a robustness check, we also estimated models using only the Voice of the People September 2002 and Gallup International Iraq Poll 2003. See the results section for details. It is important to point out that we do not make assumptions about thresholds of support. We recognize the complexity of foreign policy making and the contextual nature of leaders' political calculations. We expect only that, other things equal, more positive views, relative to negative ones, about US foreign policy will make it more likely that leaders will choose policies that the US prefers.

${ }^{30}$ The selection of countries by Gallup International is presumably based on their resources and capacity to conduct cross-national surveys, rather than on foreign policy decisions of non-US countries (or Gallup International's consideration/expectation of these decisions). Thus, we think that our estimation does not necessarily suffer from selection bias. See the results section for a robustness test that attempts to cope with the selection issue.
} 
Second, and more importantly, the question asked is suitable for testing our hypotheses. It asks directly about the (perceived) impact of US policy on the respondent's country. Thus it measures what we intend to measure theoretically - the public's general perceptions of US foreign policy that are of political relevance for decision makers.

Potentially there are two alternative measures for the independent variable, but neither is linked as closely to our hypotheses. The first would be a measure of the foreign public's affinity for US culture, values, institutions and past behavior-Nye's four currencies of soft power. As we have argued, we consider these to be underlying factors without direct relevance to foreign policy decisions. It seems sensible to assume that from the perspective of foreign policy decision makers, it is more important to know what the general public thinks about US policy when their own and/or their country's interests are concerned than to know the extent of favorable attitudes across these four currencies or even general favorability for the US. ${ }^{31}$

Another measure would be a question closely related to a specific policy issue - such as a question about sending (or not sending) troops to Iraq. As we argued in the previous section, however, soft power implies general effects across issue-areas. Therefore, overly specific operational definitions are not suitable for examining soft power processes. Furthermore, even if there existed three distinct issue-specific survey questions, ${ }^{32}$ it would be difficult to test our hypotheses without using the same independent variable. Methodologically, our study is similar to a nonequivalent dependent variables (NEDV) design in experimental research. ${ }^{33}$ By using the same variable to predict somewhat different dependent variables, we can be more confident about the (internal) validity of our findings.

The three policy-related dependent variables in our study differ in terms of their degree of salience for non-US publics. As we emphasize above, these three policy decisions were announced after the field dates of the surveys that measure our causal variable. Thus, reverse causality in the form of decisions affecting opinion in our analysis is implausible. We acknowledge, however, the issue of elite influence on public opinion prior to a decision being publicly announced or implemented. If

${ }^{31}$ As a robustness test, we use survey items measuring favorability toward the American people and the US as instrumental variables (IV). See the results section.

${ }^{32}$ Another fundamental problem is that such questions are typically included in a multinational study only when issues became salient, a situation that would make it difficult or impossible to test our second hypothesis. There are no questions about the ICC or UNGA votes, for example, in any multinational surveys of which we are aware.

${ }^{33}$ Cook and Campbell 1979, chap. 2. 
decision makers intend to take an action that is controversial (such as sending troops to Iraq) and/or salient for the public, it is plausible that they might attempt to sway public opinion prior to the announcement of the decision. ${ }^{34}$ We conduct robustness tests in connection with this potential risk of omitted variable bias in the results section. In the following discussion of our three issues (and associated dependent variables), we also present some qualitative evidence, mainly from sets of comparable countries, supporting our expectations regarding the causal effect of opinion on foreign policy outcomes.

The first dependent variable (Sent troops to Iraq in 2003) is coded 1 if a country sent troops to Iraq by the end of 2003 and 0 otherwise. ${ }^{35}$ Most countries that had sent troops to Iraq as of 2009 did so by the end of 2003. ${ }^{36}$ For this reason, we focus on decisions made by the end of 2003. The focus on this period is also useful because decisions by "latecomers," such as Japan, are likely influenced by political factors that are consequences of the postwar situation in Iraq. ${ }^{37}$ Furthermore, if we expand our period of investigation beyond December 2003, we would also need to model the decisions of countries to withdraw troops from Iraq, which began to happen in February 2004. ${ }^{38}$

Clearly, whether to send troops to Iraq was an important, if not the most important, decision for many countries during the period of our study. In 2002, US president George W. Bush, in his State of the Union address to Congress, pointed to Iraq, along with Iran and North Korea, as part of an "axis of evil" and started pressing Iraq to accept unfettered inspections for weapons of mass destruction (WMD). He and other top members of his administration began calling for a "coalition of the willing" to stand against Iraq. ${ }^{39}$ Policy debates heated up worldwide and news media focused on issues and problems in Iraq, and on

${ }^{34}$ Erikson, MacKuen, and Stimson 2002; Berinsky 2009; Stimson 2004; and Zaller 1992.

${ }^{35}$ The data were collected and cross-checked using several sources: http://www.globalsecurity.org/ military/ops/iraq_orbat_coalition.htm; http://geocities.com/jdejoannis/Coalition/\#coalition; http:// www.mod.uk/DefenceInternet/FactSheets/OperationsFactsheets/OperationsInIraqFactsandFigures .htm; http://www.mil.gov.ua/index.php?part=peacekeeping\&lang=en; http:/www.defence.gov.au/ pfalconer/; http://en.wikipedia.org/wiki/Multinational_force_in_Iraq; and various news media articles.

${ }^{36}$ Tago 2009.

${ }^{37}$ Methodologically, these factors can be influenced by both our independent and dependent variables and thus difficult to deal with. Note that variables that are at least in part consequences of the causal variable must be dropped to avoid posttreatment bias (Rosenbaum 1984).

${ }^{38}$ Although it is worth examining how non-US public opinion affected both deployment and withdrawal decisions (and/or decisions to shift troops from Iraq to Afghanistan), conducting such time-series or event-history analysis would be difficult for various methodological reasons. Most importantly, we have only limited data for time-series or event-history analysis of the effects of public opinion on policy decisions; sufficient data of that type would require multinational surveys conducted with regularity (for example, monthly or at least yearly) in a sufficiently large number of countries.

${ }^{39}$ For example, see Dao 2002; Kessler and Graham 2003; and Loeb and Ricks 2002. 
US intentions. When foreign policy makers make decisions on such a highly salient and well-known issue, public opinion should be an important matter of consideration. Therefore, we expect our independent variable to have a large, positive, and significant effect on the first dependent variable. ${ }^{40}$

Evidence from previously published case studies suggests initial support for our expectations about the causal effect of opinion about US foreign policy on countries' choices regarding the US-led war in Iraq. For example, consider the cases of Bulgaria and Turkey. Leaders in both countries had strong strategic incentives to support the US in Iraq and publicly expressed their preferences. Specifically, Bulgaria's leadership hoped that participation in the Iraq conflict would translate into US support for its admission into the NATO alliance. ${ }^{41}$ Turkey's leaders hoped for a key role in determining the postwar order in their region, especially regarding preventing Iraqi Kurds from moving toward independence and strengthening the influential Turkish military's traditional close ties with its NATO ally. They also expected financial support of $\$ 26$ billion promised by the US in exchange for use of an airbase and other facilities. Despite this similarity in leaders' inclination toward support for the US, however, these two countries experienced different trajectories: while Bulgaria was able to follow through on its decision to send troops to Iraq, the Turkish cabinet's choice to participate in the US-led war was overruled by a parliamentary vote heavily influenced by public opinion. ${ }^{42}$

In Bulgaria, 15 percent of Bulgarians had favorable views of the effect of US foreign policy on their country, and 28 percent had negative views in the September 2002 Gallup Voice of the People survey. ${ }^{43}$ While there were protests in Sofia and other cities and the Socialist Party leader spoke out against Bulgaria's participation, the majority of Bulgarians professed neutrality (or expressed indeterminate attitudes), ${ }^{44}$

${ }^{40}$ We note that Keohane and Katzenstein (2007, 290-91) find no association in a correlational analysis of opinion about the US and countries that joined the forty-nine-member "coalition of the willing" as reported by the US. However, inclusion on this list does not necessarily imply the serious step of troop commitments (as opposed to financial or other sorts of support) and apparently did not always even imply the country's actual consent, as Keohane and Katzenstein themselves point out in the case of Turkey. Thus, the foreign policy outcome they study is clearly heterogeneous across countries on their list, and this might help explain why their finding differs from ours.

${ }^{41}$ Vassilev 2006.

${ }^{42}$ Kesgin and Kaarbo 2010; Vassilev 2006.

${ }^{43}$ Vassilev $(2006,468)$ characterizes Bulgarian opinion as opposed to the country's participation in the war, but he does not take a comparative perspective. In our sample of countries, Bulgaria was above the median in the positive views of US foreign policy (see Table 2).

${ }^{44}$ Those include respondents who thought the US foreign policy has no effect on their country, who refused to answer, or who chose the "Don't Know" option. See also Vassilev 2006, 476-77. 
rather than strong opposition to Bulgarian participation, and "anti-war protests were relatively muted and only occasionally spilled out into the streets." ${ }^{5}$ In February 2003, the Bulgarian parliament supported participation in Iraq by a vote of 165 to 0 , with 48 abstentions from the Socialist Party. ${ }^{46}$

By contrast, in Turkey, while the percentage of people with positive views was similar (14 percent), a much larger share of people (66 percent) expressed negative attitudes. In response to Turkish leaders' requests, the US offered a large financial package and agreed to Turkish involvement in Northern Iraq, including the possible deployment there of as many as forty thousand Turkish troops. Despite the leaders' positions and initial agreements between Turkey and the US, Turkish parliamentarians "received [from the general public], daily, hundreds of text messages: 'Say No to War."'47 Finally, on March 1, 2003, "the Turkish Grand National Assembly (TGNA), surprised the United States and much of the world when it refused to ratify the Turkish cabinet's decision to permit the United States to use Turkey as a base for its northern front as part of the US intervention into Iraq." ${ }^{48}$ Turkey's legislators, constitutionally required to approve any foreign troop presence, "ultimately chose to listen to the voice of the public opinion, not to that of the government leadership." ${ }^{49}$

Comparing the cases of Canada, the United Kingdom, and Australia is also suggestive. These traditional US allies all provided troops to the US-led effort in Afghanistan and seriously considered sending troops to Iraq. In the end, Australia and the UK did so, but public opinion was a "significant" part of the Canadian decision not to. ${ }^{50}$ Views regarding US foreign policy were more positive in Britain and Australia prior to their decisions, with 30 percent of Britons and 31 percent of Australians believing US foreign policy had a positive effect on their country, and 42 percent of Britons and 51 percent of Australians believing it was negative in the January 2003 Gallup International Iraq Poll. The differences between positive and negative responses were 12 and 20 percentage points, respectively. In contrast, only 22 percent of Canadians had positive responses and 53 percent had negative responses, a difference of 31 percentage points.

\footnotetext{
${ }^{45}$ Vassilev 2006, 482.

${ }^{46}$ Vassilev 2006, 476-77.

${ }^{47}$ Kesgin and Kaarbo 2010, 27, 30.

${ }^{48}$ Kesgin and Kaarbo 2010, 19.

${ }^{49}$ Gozen, quoted in Kesgin and Kaarbo 2010, 32.

${ }^{50}$ O'Connor and Vucetic 2010.
} 
Before Canadian prime minister Jean Chrétien publicly ruled out participation in Iraq, his defense minister twice stated on national television that Canadian troops might participate. Comparing Canada and Australia, O'Connor and Vucetic argue that "limited national support for the war, and the particularly low level of support for the war in Quebec, was crucial to Chrétien's decision not to send Canadian troops to Iraq. . . . The Australian government clearly saw opposition to entering a US-led war as sizeable, but not politically insurmountable. In Canada, on the other hand, public sentiment was more clearly opposed to the war and is likely to have had a direct impact on the decision not to send troops." ${ }^{1}$

Our second dependent variable (BIA entered into force in 2003) is coded 1 if a so-called Article 98 agreement between a given country and the US entered into force by the end of 2003, and 0 otherwise. The Rome Statute establishing the ICC was signed by 120 states in July 1998, and it entered into force after ratification by 60 states in July 2002..$^{52}$ The Statute includes, however, Article 98(2), which states: "The Court may not proceed with a request for surrender which would require the requested State to act inconsistently with its obligations under international agreements pursuant to which the consent of a sending State is required to surrender a person of that State to the Court, unless the Court can first obtain the cooperation of the sending State for the giving of consent for the surrender." In mid-2002, President Bush explicitly repudiated any US intention to join the ICC and, based on Article 98, began negotiating bilateral immunity agreements (BIAs) with ICC members and nonmembers, so that no US nationals could be surrendered to the ICC from these countries without US consent. Pressure from the US could be intense, involving threats to cut military aid as well as a range of country-specific punishments and inducements. ${ }^{53}$ The agreements began entering into force early in 2003, and ninetyfive such agreements were concluded as of $2011 .^{54}$ Importantly, over half (fifty-four) of these countries put the agreements into force within a short period from May to December 2003. ${ }^{55}$

The US rationale for Article 98 agreements was explained by State Department spokesman Richard Boucher in 2003:56 "United States

\footnotetext{
${ }^{51}$ O'Connor and Vucetic 2010, 531, 533-34.

${ }_{52}$ As of 2011, there are 115 states that are parties to the ICc. At http://www.icc-cpi.int/Menus/ ASP/states+parties/.

${ }^{53}$ Johansen 2006; Kelley 2007.

${ }^{54} \mathrm{http}: / / w w w .11$. georgetown.edu/guides/article_98.cfm.

${ }_{55}$ Four agreements entered into force before May 2003 (Uzbekistan, Tuvalu, Egypt, and Gabon), but these countries are not included in Gallup International surveys.

${ }^{56} \mathrm{http} / /$ www.state.gov/r/pa/prs/ps/2005/45573.htm.
} 
military forces, civilian personnel and private citizens are currently active in peacekeeping and humanitarian missions in more than 100 countries. Article 98 Agreements . . . allow the United States to remain engaged internationally with our friends and allies by providing American citizens with essential protection from the jurisdiction of the International Criminal Court, particularly against politically motivated investigations and prosecutions."

Although it is a potentially important decision for another government to enter into such an agreement with the US, we assume that foreign publics are less aware of this issue and/or simply do not care much about it. Boduszyński and Balalovska show through case studies of the issue in Croatia and Macedonia that, even when the BIA debate was highly politicized due to pressure from the US to sign BIAS and from the European Union not to sign, public opinion was at best only one factor among several figuring in a country's decision. ${ }^{57}$ For example, in addition to the importance of a US threat to cut military aid, Macedonia's decision to sign a BIA appeared to be influenced by the fact that "the United States enjoys especially strong support among ethnic Albanians, who have significant influence in the current [2003] government." 58 Boduszyński and Balalovska suggest that Croatia's decision not to sign was also taken with some consideration given to public opinion: "although NATO (and the funds for military reform needed to join the organization) remained an important foreign policy goal for Croatia, the EU is more popular in Croatia. According to [October 2003] public opinion research, 78 percent of the Croatian population supports EU membership, whereas only 58 percent supports NATO accession ... [and] dissatisfaction with the United States had been rising in Croatian public opinion for myriad reasons" 59

Kelley's four brief case studies provide similar evidence-only in Costa Rica, where a local judge was nominated to sit on the ICC, is there evidence of strong domestic opposition to a BIA among the mass public. ${ }^{60} \mathrm{~A}$ former Costa Rican diplomat argued: "[The judge's] election resulted in public displays of joy and praise for Costa Rica's support for human rights... G Given that the public is very pro ICC, the president could not afford to cause another public uproar." ${ }^{61}$ But there is less evidence of public opinion as an important factor in the BIA

\footnotetext{
${ }^{57}$ Boduszyński and Balalovska 2004.

${ }^{58}$ Boduszyński and Balalovska 2004, 21.

${ }^{59}$ Boduszyński and Balalovska 2004, 25.

${ }^{60}$ Kelley 2007, 584-85.

${ }^{61}$ Quoted in Kelley 2007, 584-85.
} 
decisions of Australia, Botswana, or Estonia. In Botswana, Kelley notes a "domestic reaction" among news media, opposition parties, and NGOs, but anticipation of this did not deter the government from signing a BIA, nor did it cause a policy reversal after it signed. In Australia, opposition politicians and NGOs spoke out against a BIA, but the government appeared driven more by legal arguments than popular awareness in its eventual refusal to sign. ${ }^{62}$ In general, we see it as unlikely to be very salient or entail serious potential political costs (or benefits) for leaders. Therefore, we expect that opinion about US foreign policy will have a relatively small effect, if any, on Article 98 decisions.

The final variable (UN voting with US in 2003) is the proportion of “important" UN resolutions in 2003, on which voting by a given country and the US are the same. ${ }^{63}$ By law, the US State Department must track the voting behavior of UNGA members on resolutions and other matters deemed to be of most importance to the US, especially as they relate to the State Department's official "strategic goals." Each year the State Department issues a report to the US Congress identifying the "important votes" and how the US and other UNGA members voted on these items. For the 58th UNGA in 2003, there were fifteen such votes. These included resolutions on the US embargo against Cuba, the rights of Palestinians, Israeli occupied territories, Palestinian refugees, Israeli human rights practices in the occupied territories, confidence building in South Asia, the UN register of conventional arms, human cloning, rights of children, democracy promotion, globalization and human rights, human rights in Turkmenistan, human rights in Iran, human rights in the Democratic Republic of Congo, and UNGA reforms. ${ }^{64}$

To perhaps a greater extent than in the case of Article 98 agreements, we expect that the impact of public opinion on UN voting decisions is small, if not nil. Knowing that these issues are "important" for the U.S., policymakers in other countries may consider whether their decisions at UNGA are consistent with the general feeling of their nationals toward US foreign policy. However, these UN votes, largely symbolic, are less likely to be salient to mass publics in most countries.

${ }^{62}$ Kelley 2007, 583-86. It should be noted that Kelley reports no effect of public opinion regarding the US on whether a country signs a BIA based on a simple difference of means test. This briefly reported result also forms a considerable part of the evidence for Keohane and Katzenstein's (2007, 289) conclusion that anti-American sentiments have little or no soft power effect. However, the specific question Kelley addresses is more limited than ours, since she is interested only in factors determining whether a country that has become a party to the ICC will subsequently sign a BIA with the US.

${ }^{63} \mathrm{http}: / /$ www.un.org/Depts/dhl/resguide/gares1.htm.

${ }^{64} \mathrm{http}: / /$ www.state.gov/p/io/rls/rpt/. The UNGA reforms resolution "Provisional Program of Work for the Second Committee, A/Dec/58/554" is not included in our data because the vote outcome is unavailable from the UN database. Thus, the denominator of this variable is 14 rather than 15. 
Nevertheless, at the extremes of the data, we find some evidence of a possible causal effect. Russian public opinion about US foreign policy took a strong negative turn in reaction to US involvement in the former Yugoslavia in the 1990s, well prior to the time frame of our study. This "resulted in considerable domestic pressure on the Russian government to take more anti-American foreign policy stances." ${ }^{5}$ In UN General Assembly voting, as Voeten notes, "[ $\mathrm{t}$ ]he trend for Russia's ideal point is virtually flat until 1994 when it accelerates away from the United States at a rapid pace." ${ }^{66}$ Albanian opinion about US foreign policy, by contrast, was strongly boosted by the US role in the former Yugoslavia, "particularly after the US-led Kosovo campaign" in defense of ethnic Albanian Kosovars. Thus "every government in Albania has defined its policy toward the United States based on its national interest and the widespread positive feeling of the Albanian people toward the United States." ${ }^{67}$ Albania is the Muslim majority country with by far the highest consistency in its 2003 UNGA voting record with the US. ${ }^{68}$

Tables 1 and 2 provide a list of the fifty-eight countries in our data and the values of our independent and dependent variables. Table 1 includes the twenty-nine countries with below-median values for Opinion about US foreign policy, while Table 2 includes the twenty-nine countries above the median. The average of Opinion about US foreign policy is -0.36 for the bottom twenty-nine and 0.07 for the top twenty-nine. Overall, from mid-2002 to mid-2003, global public opinion about US foreign policy was more negative than positive.

Simple comparison of our dependent variables between the two groups suggests the plausibility of our hypotheses. First, among the bottom twenty-nine countries, only 21 percent sent troops to Iraq in 2003, but this goes up sharply to 55 percent among the top twentynine countries. Second, among the bottom twenty-nine countries, 10 percent had a BIA in effect with the US by the end of 2003, whereas this triples, to 31 percent, among the top twenty-nine countries with more favorable public opinion about US foreign policy. Finally, the percentage of UNGA votes consistent with those of the US is almost the same between the two groups, 52 percent for the bottom twenty-nine and 51 percent for the top twenty-nine. In short, these tables indicate that the effect of public opinion on foreign policy is likely to be larger if the issue at stake is important and relevant for publics.

${ }^{65}$ Voeten 2004, 733; McFaul 1997.

${ }^{66}$ Voeten 2004, 742.

${ }^{67}$ Binaj 2004, 75 .

${ }^{68}$ Bosnia Herzegovina is only 48 percent Muslim but also voted less often with the US than did Albania. 
TABLE 1

Observations, below the Median of Causal Variable ${ }^{a}$

\begin{tabular}{|c|c|c|c|c|}
\hline County & $\begin{array}{c}\text { Opinion } \\
\text { about US } \\
\text { Foreign Policy }\end{array}$ & $\begin{array}{l}\text { Sent Troops } \\
\text { to Iraq } \\
\text { in } 2003\end{array}$ & $\begin{array}{c}\text { BLA Entered } \\
\text { into Force } \\
\text { in } 2003\end{array}$ & $\begin{array}{l}\text { UN Voting } \\
\text { with US } \\
\text { in } 2003\end{array}$ \\
\hline France & -0.560 & 0 & 0 & 0.667 \\
\hline Vietnam & -0.560 & 0 & 0 & 0.000 \\
\hline Turkey & -0.524 & 0 & 0 & 0.333 \\
\hline Argentina & -0.505 & 0 & 0 & 0.417 \\
\hline Switzerland & -0.458 & 0 & 0 & 0.583 \\
\hline Russia & -0.437 & 0 & 0 & 0.417 \\
\hline Yugoslavia & -0.430 & 0 & 0 & 0.667 \\
\hline Ecuador & -0.420 & 0 & 0 & 0.500 \\
\hline Netherlands & -0.401 & 1 & 0 & 0.667 \\
\hline Uruguay & -0.390 & 0 & 0 & 0.417 \\
\hline Spain & -0.371 & 1 & 0 & 0.667 \\
\hline Greece & -0.370 & 0 & 0 & 0.667 \\
\hline South Korea & -0.363 & 1 & 0 & 0.500 \\
\hline Japan & -0.355 & 0 & 0 & 0.583 \\
\hline Germany & -0.346 & 0 & 0 & 0.667 \\
\hline Bosnia-Herzegovina & -0.307 & 0 & 1 & 0.583 \\
\hline Brazil & -0.303 & 0 & 0 & 0.417 \\
\hline Pakistan & -0.301 & 0 & 1 & 0.167 \\
\hline Austria & -0.300 & 0 & 0 & 0.667 \\
\hline Canada & -0.289 & 0 & 0 & 0.583 \\
\hline Malaysia & -0.288 & 0 & 0 & 0.167 \\
\hline Bolivia & -0.287 & 0 & 0 & 0.500 \\
\hline Finland & -0.282 & 0 & 0 & 0.667 \\
\hline Macedonia & -0.268 & 1 & 1 & 0.727 \\
\hline Norway & -0.257 & 1 & 0 & 0.667 \\
\hline Luxembourg & -0.239 & 0 & 0 & 0.667 \\
\hline Sweden & -0.238 & 0 & 0 & 0.667 \\
\hline Indonesia & -0.223 & 0 & 0 & 0.250 \\
\hline New Zealand & -0.220 & 1 & 0 & 0.583 \\
\hline Mean & -0.355 & 0.207 & 0.103 & 0.519 \\
\hline St. Dev. & 0.099 & 0.412 & 0.310 & 0.186 \\
\hline
\end{tabular}

${ }^{\text {a }}$ For our causal variable (Opinion about US foreign policy), we use the average ratios (positive and negative) for the survey item "Generally, do you think American foreign policy has a positive effect on <your country>, a negative effect or does American foreign policy have no effect on <your country >?" in surveys conducted by Gallup International from June 2002 to May 2003. 
TABLE 2

Observations, above the Median of Causal Variable ${ }^{\mathrm{a}}$

\begin{tabular}{|c|c|c|c|c|}
\hline County & $\begin{array}{c}\text { Opinion } \\
\text { about US } \\
\text { Foreign Policy }\end{array}$ & $\begin{array}{l}\text { Sent Troops } \\
\text { to Iraq } \\
\text { in } 2003\end{array}$ & $\begin{array}{c}\text { BLA Entered } \\
\text { into Force } \\
\text { in } 2003\end{array}$ & $\begin{array}{l}\text { UN Voting } \\
\text { with US } \\
\text { in } 2003\end{array}$ \\
\hline India & -0.193 & 0 & 1 & 0.250 \\
\hline Australia & -0.160 & 1 & 0 & 0.833 \\
\hline Denmark & -0.158 & 1 & 0 & 0.667 \\
\hline Italy & -0.151 & 1 & 0 & 0.667 \\
\hline Cameroon & -0.147 & 0 & 1 & 0.250 \\
\hline United Kingdom & -0.137 & 1 & 0 & 0.667 \\
\hline Bulgaria & -0.116 & 1 & 0 & 0.667 \\
\hline Guatemala & -0.069 & 0 & 0 & 0.417 \\
\hline Uganda & -0.015 & 0 & 1 & 0.167 \\
\hline South Africa & -0.012 & 0 & 0 & 0.167 \\
\hline Portugal & -0.006 & 1 & 0 & 0.667 \\
\hline Lithuania & 0.000 & 1 & 0 & 0.667 \\
\hline Kenya & 0.005 & 0 & 0 & 0.167 \\
\hline Iceland & 0.018 & 1 & 0 & 0.667 \\
\hline Ireland & 0.031 & 0 & 0 & 0.667 \\
\hline Estonia & 0.035 & 1 & 0 & 0.667 \\
\hline Poland & 0.049 & 1 & 0 & 0.667 \\
\hline Latvia & 0.070 & 1 & 0 & 0.667 \\
\hline Nigeria & 0.091 & 0 & 1 & 0.250 \\
\hline Croatia & 0.118 & 0 & 0 & 0.667 \\
\hline Colombia & 0.167 & 0 & 1 & 0.417 \\
\hline Romania & 0.171 & 1 & 0 & 0.667 \\
\hline Costa Rica & 0.172 & 0 & 0 & 0.500 \\
\hline Georgia & 0.172 & 1 & 1 & 0.500 \\
\hline Panama & 0.204 & 0 & 1 & 0.417 \\
\hline Peru & 0.249 & 0 & 0 & 0.500 \\
\hline Philippines & 0.370 & 1 & 1 & 0.250 \\
\hline Dominican Republic & 0.387 & 1 & 0 & 0.500 \\
\hline Albania & 0.785 & 1 & 1 & 0.667 \\
\hline Mean & 0.066 & 0.552 & 0.310 & 0.514 \\
\hline St. Dev. & 0.207 & 0.506 & 0.471 & 0.198 \\
\hline
\end{tabular}

${ }^{\text {a }}$ For our causal variable (Opinion about US foreign policy), we use the average ratios (positive and negative) for the survey item "Generally, do you think American foreign policy has a positive effect on <your country>, a negative effect or does American foreign policy have no effect on <your country>?" in surveys conducted by Gallup International from June 2002 to May 2003. 
A closer look at these tables, however, suggests some other systematic differences between countries in these two groups. For example, many European and/or developed countries tend to have lower values of our independent variable. They are also less likely to have an effective BIA with the US in 2003, although they are more likely to have troops in Iraq at the end of 2003. To allow us to estimate the effect of public opinion about US foreign policy, we include a range of control variables potentially correlated with our independent and dependent variables. ${ }^{69}$

We include two variables expected to have strong correlations with the first two dependent variables (troops in Iraq and BIAs) and possible correlation with the other (UN voting). Troops in Afghanistan is a dummy variable measuring whether or not a country had troops in Afghanistan in 2002. ${ }^{70}$ ICC member is a dummy variable indicating whether or not a country is an ICC member as of the end of $2002 .^{71}$

Countries with troops in Afghanistan (there are nineteen in our data) are likely either to be important US allies and/or to have sufficient military capability to send troops abroad. Thus, as compared with others, they are also more likely to have sent troops to Iraq by the end of 2003. This variable is clearly relevant as it is expected to affect our independent variable - the perceptions about US foreign policy by non-US publics as of late 2002 or early 2003 (before the war in Iraq began). ${ }^{72}$

Nonmembership in the ICC (there are sixteen instances in our data) probably indicates a state's opposition to the ICC for its own domestic or foreign policy reasons. This would presumably significantly reduce the costs of signing a BIA with the US (note that non-ICC members can also sign them), and thus it is an important factor to control to avoid a biased estimate of the effect of public opinion.

We also include five variables measuring hard power-related security and economic factors. These correspond to the likelihood, in Nye's framework, of "threats and inducements" affecting opinion and decisions.

\footnotetext{
${ }^{69}$ Since all these variables are only added for better control, we are not interested here in their statistical and substantive effects and do not discuss the expected direction of effect parameters or their estimates.

${ }^{70}$ Data were collected and cross-checked using several sources: NATO's SHAPE Public Affairs Office for International Security Assistance; http://en.wikipedia.org/wiki/Operation_Enduring_Freedom __Afghanistan:_Allies; http://www.defenselink.mil/new/Jun2002/d20020607contributions.pdf; http:// www.globalsecurity.org/military/ops/enduring-freedom_deploy.htm; http://www.mil.be/isaf/subject/ index.asp?:LAN=nl\&ID=1213; and several press reports.

${ }^{71}$ The data source is http://www.icc-cpi.int/asp/statesparties.html.

${ }^{72}$ We also think that the observed variable for troop commitment in Afghanistan (as of 2002) may be a proxy for the expected variable for troop commitment in Iraq (that is, an expectation about decisions in 2003, formed in 2002), which should be correlated with our causal variable.
} 
Alliance portfolio measures the commonality in alliance "portfolios" between the US and each country, as of 2000. It is developed by Signorino and Ritter and widely used in quantitative studies of international relations as a measure of common security interests. ${ }^{73}$ Another alliance indicator, $N A T O$, is a dummy variable for members of the North Atlantic Treaty Organization as of 2002. US economic aid and US military aid measure the per capita amount of US military and economic aid to each country in 2002. ${ }^{74}$ Trade with US is the natural log of the total amount of trade (export and import) with the US divided by each country's GDP (in 2002). ${ }^{75}$

The remaining variables are reasonable proxies for economic, political, cultural, and historical relationships (or the lack of such relationships) with the US. GDP per capita is the natural log of GDP per capita in 2002. ${ }^{76}$ Democracy score is the sum of two indicators (political rights and civil liberties, for 2002) published annually by Freedom House. ${ }^{77}$ Muslim population is the ratio of Muslims in the total population before 2002. ${ }^{78}$ Europe is a dummy variable for West European countries, which include the so-called EU 15 (member countries in the European Union prior to the accession of ten candidate countries on May 1, 2004), Norway, and Switzerland.

Finally, in order to address a potential criticism, we emphasize a basic methodological point. As long as we do not expect, in theory, that certain variables have direct effects on policy decisions by non-US states, we need not include them in our analysis. These would include a range of soft power variables, such as public diplomacy efforts by the US, exports of US culture to foreign nations, and visits by US sport and music stars. The omission of these variables should not lead to biased causal estimates, because, as our theoretical framework specifies, if they have any effect on our dependent variables (that is, policy decisions),

\footnotetext{
${ }^{73}$ Signorino and Ritter 1991; the data source is EUGene data-generation software. At http://www .eugenesoftware.org/.

${ }_{74}$ The data source is the "Green Book" on loans and grants. At http://qesdb.cdie.org/gbk/. We code 0 for missing observations. The unit is 2006 US dollars.

75 The data source is the International Monetary Fund's Data and Statistics Web site. At http:// www.imf.org/external/data.htm. The unit (for exports, imports, and GDP) is current US dollars.

${ }^{76}$ The data source is the World Bank's World Development Indicators (WDI) Online. At http:// publications.worldbank.org/WDI/. The unit is constant 2005 international dollars in PPP.

77 The data source is http://www.freedomhouse.org. We do not use another commonly used measure of democracy, Polity score, because it is not coded for three countries surveyed by Gallup International-Luxembourg, Bosnia and Herzegovina, and Iceland. The correlation between Democracy score and Polity score is high (0.834).

${ }^{78}$ The data source is http://islamicweb.com/. We code 0 for missing observations. This is the best comprehensive data source we could find for pre-2003 figures. Specific dates for each country's percentage are not given, but the Web site implies they are current as of 1998 .
} 
this should only be through changing public opinion about US foreign policy, our independent variable. ${ }^{79}$

\section{RESULTS}

We estimate two sets of regressions for each dependent variable-one without the covariates and another with them. Since the first two dependent variables (Sent troops to Iraq in 2003 and BIA entered into force in 2003) are dichotomous, we estimate the coefficients based on probit regressions. The effects on the third dependent variable ( $U N$ voting with US in 2003) are estimated by OLS regressions.

The results of our regression analysis are presented in Table 3. Without control variables, the effect of Opinion about US foreign policy is positive and significant on the first two dependent variables, but it is negative and insignificant on the third dependent variable. Not surprisingly, this is consistent with the patterns noted in Tables 1 and 2. The estimates with the eleven control variables, however, suggest that the feelings of non-US publics toward US foreign policy have significantly positive effects on all three dependent variables. This is expected given our framework but nevertheless striking given that a variety of variables measuring security, economic, cultural, and historical relationships with the US are controlled. This is strong evidence to support our first hypothesis that non-US public opinion indeed matters for foreign policy outcomes regarding the US.

To examine the validity of our second hypothesis, however, we need to compare the magnitude of effects across the three sets of models. Table 3 does not easily allow us to do so, because we use different methods of estimation (probit and oLs) and because the interpretation of probit coefficients is not straightforward. To interpret substantive effects and test our second hypothesis, we simulate the marginal effect of our independent variable on each dependent variable when it changes from one standard deviation below the mean to one standard deviation above the mean. All control variables are held constant at their means. The results are graphically presented in Figure 2. We also simulated the degree of uncertainty: each vertical bar indicates the 95 percent confidence interval of the estimated probability (for the first two dependent variables) and the expected value (for the third dependent variable). ${ }^{80}$

\footnotetext{
${ }^{79}$ We use such underlying attitudinal variables as instrumental variables in a robustness test.

${ }^{80}$ To estimate uncertainty, we use a stochastic simulation technique (King, Tomz, and Wittenberg 2000).
} 
TABLE 3

REGRESSION RESULTS ${ }^{\mathrm{a}}$

\begin{tabular}{|c|c|c|c|c|c|c|}
\hline Model & 1 & 2 & \multicolumn{2}{|c|}{$\begin{array}{l}3 \\
\text { BLA Entered into } \\
\text { Force in } 2003\end{array}$} & \multicolumn{2}{|c|}{$\begin{array}{cc}5 & 6 \\
U N \text { Voting with } \\
\text { US in } 2003\end{array}$} \\
\hline \multirow{3}{*}{$\begin{array}{c}\text { Dependent Variable } \\
\text { Opinion about US } \\
\text { Foreign Policy }\end{array}$} & \multicolumn{2}{|c|}{$\begin{array}{l}\text { Sent Troops to } \\
\text { Iraq in } 2003\end{array}$} & \multicolumn{2}{|c|}{$\begin{array}{l}\text { BLA Entered into } \\
\text { Force in } 2003\end{array}$} & \multicolumn{2}{|c|}{$\begin{array}{c}\text { UN Voting with } \\
\text { US in } 2003\end{array}$} \\
\hline & $1.90^{* *}$ & $10.26^{* *}$ & $2.04^{* *}$ & $3.33^{*}$ & 2.07 & $15.78^{* *}$ \\
\hline & {$[0.65]$} & {$[3.19]$} & {$[0.70]$} & {$[1.46]$} & {$[9.06]$} & {$[3.62]$} \\
\hline Troops in & & $4.83^{* *}$ & & -0.57 & & $6.42^{*}$ \\
\hline Afghanistan & & {$[1.75]$} & & {$[0.57]$} & & {$[2.71]$} \\
\hline \multirow[t]{2}{*}{ ICC member } & & -3.14 & & 1.58 & & 2.00 \\
\hline & & {$[1.73]$} & & {$[1.09]$} & & [3.49] \\
\hline \multirow[t]{2}{*}{ Alliance portfolio } & & $-21.34^{*}$ & & -1.34 & & 10.26 \\
\hline & & [10.09] & & {$[2.28]$} & & {$[14.01]$} \\
\hline \multirow[t]{2}{*}{ NATO } & & $7.35^{*}$ & & & & -5.74 \\
\hline & & {$[3.40]$} & & & & {$[4.02]$} \\
\hline \multirow[t]{2}{*}{ US military aid } & & $2.41^{*}$ & & $0.29 *$ & & 0.55 \\
\hline & & {$[1.02]$} & & {$[0.14]$} & & {$[0.37]$} \\
\hline \multirow[t]{2}{*}{ US economic aid } & & -0.25 & & 0.04 & & $0.46^{* *}$ \\
\hline & & {$[0.13]$} & & {$[0.03]$} & & {$[0.12]$} \\
\hline \multirow[t]{2}{*}{ Trade with US } & & 0.77 & & 0.30 & & $-4.77^{* *}$ \\
\hline & & {$[0.60]$} & & {$[0.37]$} & & {$[1.36]$} \\
\hline \multirow[t]{2}{*}{ GDP per capita } & & -0.95 & & $-1.78^{*}$ & & $12.59^{* *}$ \\
\hline & & {$[0.79]$} & & {$[0.89]$} & & {$[2.12]$} \\
\hline \multirow[t]{2}{*}{ Democracy score } & & $-1.43^{*}$ & & 0.13 & & -1.14 \\
\hline & & {$[0.66]$} & & {$[0.19]$} & & {$[0.83]$} \\
\hline \multirow[t]{2}{*}{ Muslim population } & & -4.31 & & 1.58 & & -2.51 \\
\hline & & {$[3.14]$} & & {$[1.10]$} & & {$[3.82]$} \\
\hline \multirow[t]{2}{*}{ Europe } & & $-3.32^{*}$ & & & & 0.32 \\
\hline & & {$[1.43]$} & & & & {$[3.47]$} \\
\hline \multirow[t]{2}{*}{ Constant } & -0.06 & $27.44^{*}$ & $-0.62^{* * *}$ & $13.60^{*}$ & $51.98^{* *}$ & $-81.67^{* *}$ \\
\hline & {$[0.20]$} & {$[13.44]$} & {$[0.21]$} & {$[7.98]$} & [2.69] & [29.02] \\
\hline Wald $\chi^{2}$ statistic & 8.48 & 24.87 & 8.55 & 24.13 & & \\
\hline Pseudo R ${ }^{2}$ & 0.099 & 0.756 & 0.129 & 0.671 & & \\
\hline F-statistic & & & & & 0.05 & 43.91 \\
\hline $\mathrm{R}^{2}$ & & & & & 0.001 & 0.858 \\
\hline Root MSE & & & & & 19.218 & $8.092^{* *}$ \\
\hline
\end{tabular}

${ }^{* *} p<0.01,{ }^{*} p<0.05$

${ }^{\mathrm{a}}$ The number of observations is 58 . For our causal variable (Opinion about US foreign policy), we use the average ratios (positive and negative) for the survey item "Generally, do you think American foreign policy has a positive effect on <your country>, a negative effect or does American foreign policy have no effect on <your country>?" in surveys conducted by Gallup International from June 2002 to May 2003. Models 1-4 are estimated based on probit regression, while models 5-6 are based on OLS regression. The NATO and Europe dummies are dropped in model 4 because all countries that put Article 98 into force are neither NATO members nor in Europe. The UN voting with US (a ratio in Tables 1 and 2) is multiplied by 100 (and thus is \% in this table) for better presentation of estimates. The robust standard errors are in brackets. 
$\mathrm{P}($ Sent Troops in Iraq in $2003=1)$

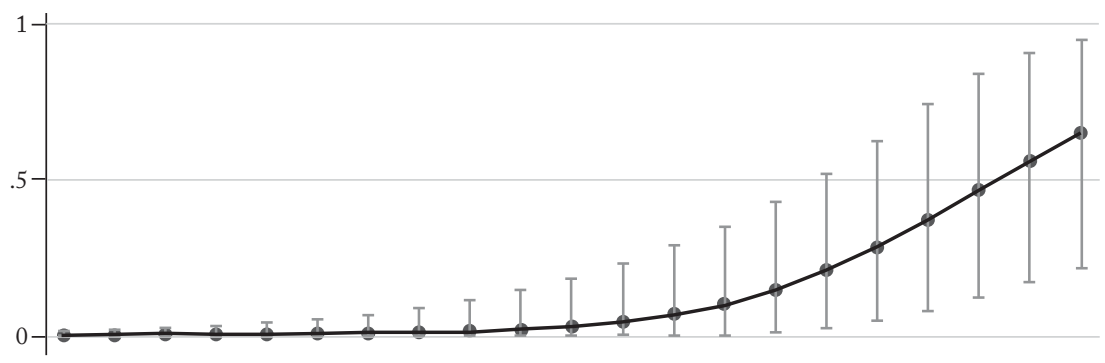

$\mathrm{P}(\mathrm{BIA}$ entered into force in $2003=1)$

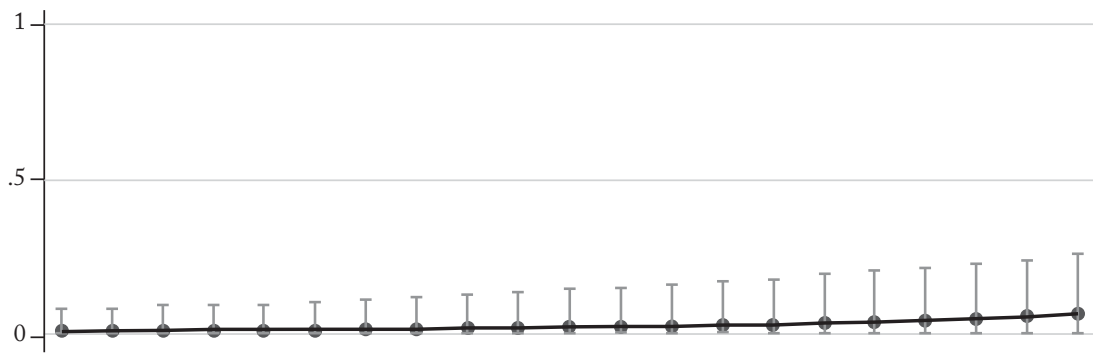

$\mathrm{E}$ ( UN voting with US, ratio )

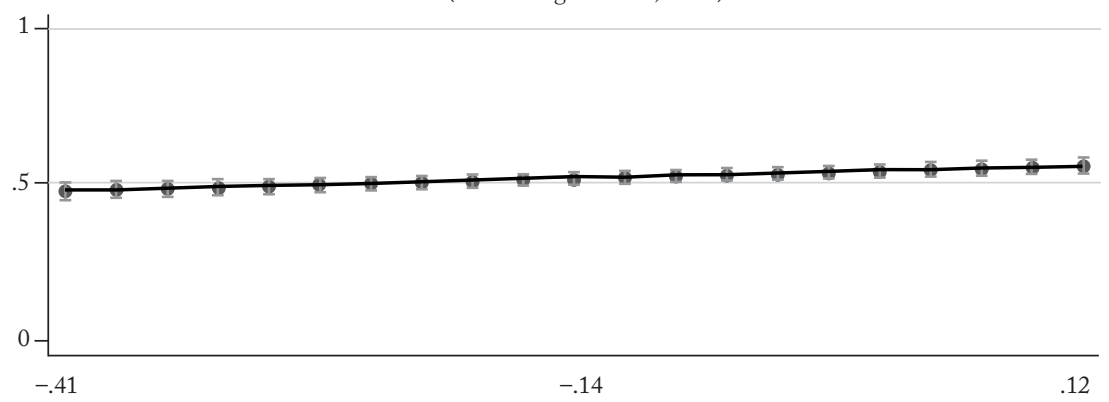

Opinion about US Foreign Policy

FiguRE 2

Marginal Effects

${ }^{\text {a }}$ Each panel shows how much each dependent variable would change if the causal variable (Opinion about US foreign policy) changed from -1 standard deviation from the mean to +1 standard deviation from the mean when all the other variables are held constant at their means. For our causal variable (Opinion about US foreign policy), we use the average ratios (positive and negative) for the survey item "Generally, do you think American foreign policy has a positive effect on <your country>, a negative effect or does American foreign policy have no effect on <your country>?" in surveys conducted by Gallup International from June 2002 to May 2003. Each vertical bar indicates the 95 percent confidence interval of estimated probability $(\mathrm{P})$ or expected value $(\mathrm{E})$. 
The figure clearly suggests the validity of our second hypothesis that the effects of public opinion on foreign policy depend on the importance of policy issues for publics. The probability of sending troops to Iraq increases dramatically from 0.2 percent to 64.1 percent when Opinion about US foreign policy changes from minus one to plus one standard deviation from the mean. Although the effects on the other two variables are positive and significant, our postestimation simulation suggests that they are small. The probability of a BIA entering into force in 2003 increases from 0.8 percent to 5.6 percent. The percentage of common UN voting decisions with the US increases from 47.5 percent to 55.8 percent.

\section{Tests of Robustness}

Through four additional analyses, we demonstrate that these results are robust to three potential sources of bias—sampling bias, selection bias, and omitted variable bias. ${ }^{81}$

First, we address an issue of potential sampling bias. We add a dummy variable for countries not using national samples. Since countries using urban samples tend to be developing countries, and since we control for GDP per capita, we expect that adding this control will not change coefficient estimates substantially. The results of this robustness check are consistent with our expectations. The effect of public opinion about the US on whether a country sent troops to Iraq in 2003 is always positive and statistically significant. Marginal effects are substantially large. The effects on the other two variables are always positive, and statistically significant in most models. As in our main models, however, the magnitudes of the effects are small.

Second, to show that our findings do not depend on the particular set of countries included in the Gallup surveys, we estimated our models using an expanded data set and a method of multiple imputation. ${ }^{82}$ Applying this method is suitable in our study, because it is only our key independent variable that has limited cross-national coverage: all three dependent variables and eleven control variables do not have missing values in most countries in the world. Analysis using the 189 countries for which we have data for all three dependent variables shows that the effect of opinion remains positive and significant in all three models with control variables. ${ }^{83}$

\footnotetext{
${ }^{81}$ In some of these additional models for robustness tests, a few covariates were dropped due to data problems (for example, multicollinearity with others). The selection of control variables, however, does not affect our conclusions.

${ }^{82}$ For example, see Rubin 1987; and Schafer 1997.

${ }^{83}$ See fn. 30 regarding selection issues.
} 
The third set of robustness tests addresses the concern, already noted, that policy elites may attempt to manipulate public opinion before an important policy decision is publicly announced or implemented. ${ }^{84}$ Given that the unannounced intention to commit troops to Iraq, sign a BIA, and/or vote with the US in the UNGA is unobservable (at least, difficult to measure with validity), this methodological issue of potential omitted variable bias is challenging to address. We approach this issue by conducting two additional robustness tests.

In one test, we drop data for the latter of the three surveys used in our analysis. ${ }^{85}$ Specifically, we rerun our analyses using only the 2002 Voice of the People Survey (June-September 2002) and the Iraq 2003 Poll (January 2003). These predate not only the point at which the US began publicly asking for troop commitments for the occupation (from May 2003, the point from which the vast majority of commitments were made) but also the initial invasion in March 2003 (involving troops from three US partners: UK, Australia, and Poland). They also predate US secretary of state Colin Powell's speech at the UN Security Council in February 2003, in which he presented intelligence on Iraq's WMD program. At that point, we believe there was still considerable uncertainty about what the time frame might be if a war were to occur and which countries might join or oppose it. We therefore believe that surveys taken from June 2002 through January 2003 measure our causal variable well prior to our outcome variable, even for those states that participated in the original invasion.

The results show that the effects of Opinion about US foreign policy on Sent troops to Iraq in 2003 and UN voting with US in 2003 are positive and significant at the 1 percent level, even after controlling for other variables. The marginal effects are smaller, but this is to be expected. The longer the gap between when public opinion is measured and when foreign policy decisions are taken, the smaller the expected strength of their association. The effect on BIA entered into force in 2003 is positive but not significant. This is not a surprising outcome, as we argue that the effects of public opinion should be small for less salient issues (hypothesis 2).

The final robustness test to deal with potential problems of omitted variable bias is to use instrumental variables that are strongly correlated with the causal variable (Opinion about US foreign policy) but

\footnotetext{
${ }^{84}$ Berinsky 2009; Zaller 1992.

${ }^{85}$ We prefer to use our data, which are based on three surveys; this reduces potential nonrandom measurement error. By using the three surveys, we also increase the number of countries in our sample, because each survey was not conducted in exactly the same set of countries.
} 
whose effects on the dependent variable occur only through the causal variable. ${ }^{86}$ Consistent with our theoretical discussion, we choose two measures of general favorability towards the US ("Do you have a favorable or unfavorable view of the US?" and "Do you have a favorable or unfavorable view of the American people?") in a multinational study conducted by the Pew Research Center for the People and the Press (Pew) before the war in Iraq began (Summer 2002 44-Nation Survey). We expect these instruments (specifically, the percentage of respondents saying "favorable" minus the percentage of respondents saying "unfavorable") to have strong correlations with our causal variable. But it is difficult to imagine that the foreign publics' favorable/unfavorable attitudes toward the US and the American people directly affect their country's important foreign policy decisions; rather, such general attitudes should affect foreign policy decisions via their effect on the foreign policy views of the mass public.

The results of our instrumental variable regressions show that the effect on Sent troops to Iraq in 2003 is still positive and significant at the 5 percent level. ${ }^{87}$ The effects on the other two less salient issues are not significant. These results remain consistent with hypothesis 2 . Since the number of observations used in this robustness test is small, we interpret the estimates with caution. ${ }^{88}$ But the results reinforce our argument regarding the direction of causation: when an issue is highly salient, public opinion about US foreign policy affects foreign policy behavior toward the US.

\section{Conclusions}

Our regression analyses are solidly consistent with our arguments. Public opinion about US foreign policy indeed appears to matter when

\footnotetext{
${ }^{86}$ We run standard two-stage least square (2sLS) regressions for all the three dependent variables. An alternative model for Sent troops to Iraq in 2003 and BIA entered into force in 2003 is to use instruments in Probit regressions. We, however, prefer to use 2sLs because it is easier to conduct comprehensive specification tests after running 2 sLS regressions, and because instrumental-variable Probit regressions do not always converge to produce coefficient estimates. In one model, which produced estimates while using as many control variables as possible (specifically, Troops in Afghanistan, ICC member, Alliance portfolio, US economic aid, trade with US, and Europe), the Wald test of instruments suggests that we fail to reject the null hypothesis of exogeneity. Therefore, we do not need to be overly concerned about endogeneity. (Note that in this model, the effect of Opinion about US foreign policy on Sent troops to Iraq in 2003 is still significantly positive at the 5 percent level and the instruments are highly significant at the 1 percent level.)

${ }^{87}$ The results of overidentification tests suggest that instruments are valid, while the results of endogeneity tests suggest that we do not need to treat Opinion about US foreign policy as an endogenous variable, in the first place.

${ }^{88}$ Only twenty-five countries are included in both the Pew study and at least one of the three surveys in our dataset.
} 
countries make decisions on issues of importance to the US. The estimated effect of public opinion about foreign policy is particularly large and robust if a specific foreign policy issue is salient for foreign publics, as we hypothesized. Foreign leaders, it seems, do pay attention to the attitudes of their own publics when they weigh decisions - such as whether to send troops into harm's way-which might incur significant public concern or opposition.

We acknowledge that while our dependent variables cover a range of issues, the period of investigation is specific. Thus, we are unwilling to make a general claim that foreign public opinion is always important for the US. In fact, our analysis may imply that it has real policy consequences only when issues are highly controversial and discussed among foreign publics extensively and intensively. ${ }^{89}$ Our study also does not examine the time frame or the full process of soft power effects. Additional empirical studies using data from other periods and using other policy variables are necessary to further understand the soft power process connecting country images, targeted messages, foreign public opinion, and foreign policy outcomes. But we believe our study lays the foundation for such future investigation.

Three decades ago, Keohane and Nye first advanced a theory of international relations that identified transnational agenda setting as a significant source of power in international relations..$^{90}$ Although we would argue that military capabilities certainly have utility in the global terrorism issue-area, it seems to us that the US has often tested the outer bounds of the utility of military force since it launched the war in Afghanistan in 2001. Even in a situation of considerable unipolar preponderance in military capabilities, the US has been far from exercising control over outcomes in many key areas.

Our analysis here is timely, given that the Obama administration seems to have placed greater emphasis on soft power than its predecessor and to have been more capable of generating a positive image for the US globally. ${ }^{91}$ Our previous research has shown the potential for the US to influence perceptions of itself and its policies abroad, as well as the constraints and limits of such efforts. ${ }^{92}$ This article provides evidence for the next necessary link in the causal chain: the impact of international public opinion on foreign policy outcomes. In sum, this study suggests not only that soft power offers appealing rhetoric for

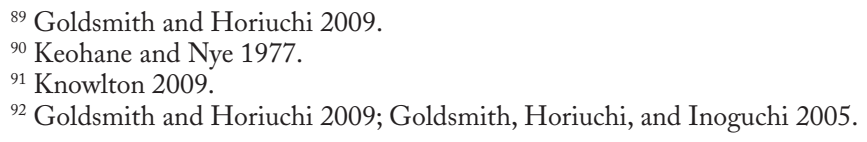


leaders or a catchy phrase for pundits but also that it has real ramifications for international relations.

\section{REFERENCES}

Bachrach, Peter, and Morton S. Baratz. 1962. "Two Faces of Power." American Political Science Review 56, no. 4: 947-52.

- 1963. "Decisions and Nondecisions: An Analytical Framework." American Political Science Review 57, no. 3: 632-42.

Berinsky, Adam J. 2009. In Time of War: Understanding American Public Opinion from World War II to Iraq. Chicago, Ill.: University of Chicago Press.

Binaj, Dhimiter. 2004. "An Analysis of United States-Albanian Security Relations in Light of the War on Terrorism." Master's thesis, U.S. Naval Postgraduate School,Monterey, Calif. At http://www.dtic.mil/cgi-bin/ GetTRDoc?AD=ada429684, accessed December 30, 2011.

Boduszyński, Mieczysław P., and Kristina Balalovska. 2004. "Between a Rock and a Hard Place: Croatia, Macedonia, and the Battle over Article 98." Problems of Post-Communism 51, no. 1: 18-30.

Cook, Thomas, and Donald Campbell. 1979. Quasi-Experimentation: Design and Analysis Issues for Field Settings. Boston, Mass.: Houghton Mifflin.

Dao, James. 2002. "Several Nations Weigh U.S. Request to Join Forces against Iraq." New York Times. November 21. At http://global.factiva.com, accessed January 6, 2009.

Datta, Monti Narayan. 2009. "The Decline of America's Soft Power in the United Nations." International Studies Perspectives 10, no. 3: 265-84.

Dragojlovic, Nicolas. 2009. "When Does Anti-Americanism Matter? Public Attitudes towards the United States and Participation in the Iraq War." Paper presented at the annual meeting of the Western Political Science Association, Vancouver, B.C., Canada, March 19. At http://www.allacademic.com/meta/ p317011_index.html.

Eichenberg, Richard C. 1989. Public Opinion and National Security in Western Europe. Ithaca, N.Y.: Cornell University Press.

. 1993. "Dual Track and Double Trouble: The Two-Level Politics of INF." In Peter B. Evans, Harold K. Jacobson, and Robert D. Putnam, eds., DoubleEdged Diplomacy: International Bargaining and Domestic Politics. Berkeley, Calif.: University of California Press.

Entman, Robert M. 2008. "Theorizing Mediated Public Diplomacy: The U.S. Case." International Journal of Press/Politics 13, no. 2: 87-102.

Erikson, Robert S., Michael B. MacKuen, and James A. Stimson. 2002. The Macro Polity. New York, N.Y.: Cambridge University Press.

Goldsmith, Benjamin E., and Yusaku Horiuchi. 2009. "Spinning the Globe? U.S. Public Diplomacy and Foreign Public Opinion." Journal of Politics 71, no. 3: $863-75$.

Goldsmith, Benjamin E., Yusaku Horiuchi, and Takashi Inoguchi. 2005. "American Foreign Policy and Global Public Opinion: Who Supported the War in Afghanistan?" Journal of Conflict Resolution 49, no. 3: 408-29.

Gourevitch, Peter. 1978. "Second Image Reversed: The International Sources of Domestic Politics." International Organization 32, no. 4: 881-912. 
Isernia, Pierangelo, Zoltán Juhász, and Hans Rattinger. 2002. "Foreign Policy and the Rational Public in Comparative Perspective." Journal of Conflict Resolution 46, no. 2: 201-24.

Jacobs, Lawrence R., and Benjamin I. Page. 2005. "Who Influences U.S. Foreign Policy?” American Political Science Review 99, no. 1: 107-23.

Kelley, Judith. 2007. "Who Keeps International Commitments and Why? The International Criminal Court and Bilateral Nonsurrender Agreements." American Political Science Review 101, no. 3: 573-89.

Keohane, Robert O., and Peter J. Katzenstein. 2007. “The Political Consequences of Anti-Americanism." In Peter J. Katzenstein and Robert O Keohane, eds., Anti-Americanisms in World Politics. Ithaca, N.Y.: Cornell University Press: 273-305.

Keohane, Robert O., and Joseph S. Nye. 1977. Power and Interdependence. Boston, Mass.: Little, Brown.

Kesgin, Baris, and Juliet Kaarbo. 2010. "When and How Parliaments Influence Foreign Policy: The Case of Turkey's Iraq Decision.” International Studies Perspectives 11, no. 1: 19-36.

Kessler, Glenn, and Bradley Graham. 2003. "U.S. Coalition for War Has Few Partners, Troop Pledges." Washington Post. January 25. At http://global.factiva .com, accessed January 6, 2009.

King, Gary, Michael Tomz, and Jason Wittenberg. 2000. "Making the Most of Statistical Analyses: Improving Interpretation and Presentation." American Journal of Political Science 44: 347-61.

Knowlton, Brian. 2009. "Global Views of US Helped by Obama, Survey Says." New York Times. At http://www.nytimes.com/, accessed July 24, 2009.

Lax, Jeffrey R., and Justin H. Philips. 2009. "Gay Rights in the States: Public Opinion and Policy Responsiveness." American Political Science Review 103, no. 3: 367-86.

Loeb, Vernon, and Thomas E. Ricks. 2002. "U.S. Asks Allies for Iraq War Support; 50 Nations Queried on Participation." Washington Post. November. At http://global.factiva.com, accessed January 6, 2009.

McCombs, Maxwell E., and Donald L. Shaw. 1972. "The Agenda-Setting Function of Mass Media.” Public Opinion Quarterly 36, no. 2: 176-87.

McFaul, Michael. 1997. "A Precarious Peace: Domestic Politics in the Making of Russian Foreign Policy.” International Security 22, no. 3: 5-35.

Nye, Joseph S. 1990. Bound to Lead: The Changing Nature of American Power. New York, N.Y.: Basic Books.

- 2004. Soft Power: The Means to Success in World Politics. New York, N.Y.: Public Affairs.

O’Connor, Brendon, and Srdjan Vucetic. 2010. “Another Mars-Venus Divide? Why Australia Said 'Yes' and Canada Said 'Non' to Involvement in the 2003 Iraq War." Australian Journal of International Affairs 64, no. 5: 526-48.

Putnam, Robert D. 1988. "Diplomacy and Domestic Politics: The Logic of TwoLevel Games.” International Organization 42, no. 3: 427-60.

Risse-Kappen, Thomas. 1991. "Public Opinion, Domestic Structure, and Foreign Policy in Liberal Democracies.” World Politics 43, no. 4 (July): 479-512.

Rosenbaum, Paul R. 1984. "The Consequences of Adjustment for a Concomitant Variable That Has Been Affected by the Treatment." Journal of the Royal Statistical Society. Series A (General) 147, pt. 5: 656-66. 
Rubin, Donald B. 1987. Multiple Imputation for Nonresponse in Surveys. New York, N.Y: Wiley.

Schafer, Joseph L. 1997. Analysis of Incomplete Multivariate Data. Boca Raton, Fla.: Chapman and Hall/CRC.

Signorino, Curtis S., and Jeffrey M. Ritter. 1999. "Tau-b or Not Tau-b: Measuring the Similarity of Foreign Policy Positions." International Studies Quarterly 43, no. 1: 115-44.

Sobel, Richard. 2001. The Impact of Public Opinion on U.S. Foreign Policy since Vietnam. New York, N.Y.: Oxford University Press.

Stimson, James A. 2004. Tides of Consent: How Public Opinion Shapes American Politics. Cambridge, UK: Cambridge University Press.

Tago, Atsushi. 2009. "When Are Democratic Friends Unreliable? The Unilateral Withdrawal of Troops from the "Coalition of the Willing." Journal of Peace Research 46, no. 2: 219-34.

Tahk, Alexander M., Jon A. Krosnick, Dean Lacy, and Laura Lowe. 2009. "Do the News Media Shape How Americans Think about Politics? New Statistical Procedures Cast Light on an Old Hypothesis." Manuscript, Stanford University.

Vassilev, Rossen. 2006. "Public Opinion and Bulgaria's Involvement in the Iraq War." Eastern European Quarterly 40, no. 4: 467-87.

Zaller, John. 1992. The Nature and Origins of Mass Opinion. New York, N.Y.: Cambridge University Press.

Zubrow, Michael. 2009. “Obama Engages the World.” вBC Nerws Online. At http:// news.bbc.co.uk/2/hi/americas/8146286.stm, accessed July 13, 2009. 